\title{
Chapter 6 \\ Why Aquinas Would Agree That Human Economic Behaviour Is Largely Predictable
}

\author{
Richard Conrad and Peter Hunter
}

\begin{abstract}
Many people, from retailers and advertisers to the Chancellor of the Exchequer, work on the assumption that human economic behaviour is to a fair degree predictable, at least statistically. This paper asks how far the thirteenthcentury Thomas Aquinas would agree that human behaviour (including economic behaviour) is predictable, both the behaviour of individuals and the behaviour of groups, and on what grounds. In doing so it also asks how any elements of predictability would square with Aquinas' conviction that human beings enjoy liberum arbitrium, "free decision". In the context of the present volume, exploring Aquinas' position may promote a nuanced and multivalent approach to the question of what causes human behaviour, and liberate us from the fear that if human behaviour is caused, it cannot be free.

Aquinas was aware of the extreme complexity of the human psyche and of the organic interactions among its components. In particular, liberum arbitrium is achieved in interaction between intellect and will. The human will is the rational appetite, the ability to be attracted by the good perceived by reason. Any predictability of behaviour is therefore not a statistical result of intrinsic arbitrary randomness, as if acts of will were a kind of mental coin-flipping. Truly free behaviour is rationally explicable in terms of the goals it is right for human beings to pursue; final causality operates, in a way appropriate to responsible agents.

In an ideal world, not marred by sin, this would make human nature predictable to a limited degree. People would behave sensibly, as individuals and as communities, avoiding anything harmful. But people naturally differ in talents and temperament; geographical and historical circumstances vary; and human thinking is open-ended - within the time available, we can examine a situation from different points of view. In an unfallen world, people would happily adopt different social roles, and leaders' decisions about how to apply the Natural Law to particular
\end{abstract}

\footnotetext{
R. Conrad $(\bowtie) \cdot$ P. Hunter $(\bowtie)$

Blackfriars Hall, Oxford University, Oxford, UK

e-mail: richard.conrad@bfriars.ox.ac.uk; peter.hunter@bfriars.ox.ac.uk
} 
circumstances would be sensible, but also "prudential" as not determined by a rigid reasoning process such as geometry uses. Within a context of good citizenship, people would make varying choices about practical matters, to the extent that an unfallen race would be more interesting and vital - because more human - than a fallen one.

Our world is not ideal. The basic dynamics of intellect, will and emotions remain good, but individual temperaments can include propensities to vice as well as to virtue. Intellect and will are in important ways blank slates at birth, and embedded in a biological and social context. In the long growth towards moral maturity people are vulnerable to corrupt customs which can obscure even obvious points of the Natural Law. Though God's grace is operative, not many people achieve the full moral freedom of an integrity in which emotions enhance a rational behaviour personally owned. When people do build up virtue, and thereby are partially liberated from the effects of the Fall, it becomes possible to predict in a general way that they will behave virtuously. But the open-endedness of thinking means that virtuous people will make varying choices about practical matters, more interesting and various than the dull and sadly predictable behaviour of people tied to various vices.

Since thorough-going vice is unnatural, most people tend towards a mediocre, partial moral consistency and behave rationally enough, obeying laws that carry sanctions, and listening to the more persuasive good advice; this will result in a certain predictability of behaviour on the part of the majority. They will also tend to follow bad laws and false persuasion without adequate reflection. Further, the failure to develop full rational control of their emotions (a control that must be "political" rather than "despotic") leaves people vulnerable to emotional drives: in the here-and-now they often perceive lesser, but easy and immediate, goods as preferable to greater goods that they know are better, but which are more demanding and distant. At the personal level, individual temperaments lead to a certain predictability of behaviour; at the social level, predictability may result from the proportion of temperaments that is statistically likely. Aquinas saw these temperaments as due to inheritance and astrological influences; we would replace astrological explanations by genetic ones and a better understanding of children's psychological development in its social context. For Aquinas, astrological influences remained potent throughout life, influencing the will indirectly, through the imagination and humours. We reject that form of predictability, but psychological experiments show that subconscious environmental factors, as well as fashion and peer-pressure, are potent. Aquinas also saw good and bad angels as influencing the human imagination and humours. Whether or not we agree with him on that, we recognise elements of unpredictability in social behaviour that are due to our vulnerability to unexpected mass movements, mass movements that we are inclined to label "demonic" - though there can also be good ("angelic") mass-movements. 
In conclusion: Aquinas would agree that human behaviour is predictable in some degree, but his perceptive pre-modern understanding of human psychology invites us to reflect afresh on the nature of freedom and on the forms and causes of predictability.

\subsection{Introduction}

Many people, from retailers and advertisers to the Chancellor of the Exchequer, assume that human economic behaviour is to a fair degree predictable, at least statistically. They expect forms of persuasion, and fashion, to cause enough people to buy certain goods to make advertising, or stocking up on certain goods, profitable. They predict that increasing the tax on tobacco will cause a worthwhile proportion of smokers to quit the habit. This paper examines how far Thomas Aquinas would agree that the behaviour of individuals and of groups is predictable, and on account of what factors. In doing so it will touch on how elements of predictability would square with his conviction that human beings enjoy liberum arbitrium, "free decision".

Aquinas ${ }^{1}$ says little on economic behaviour as such, ${ }^{2}$ but is worth including in this volume because he worked before 1277. In that year certain "Aristotelian" propositions were condemned by Paris and Oxford Universities, an event David Luscombe describes as a "watershed". ${ }^{3}$ Aquinas and Bonaventure disagreed about the relative priority of intellect and will, but agreed that free decisions arise within the interaction of these components of human nature. ${ }^{4}$ Scotus, working after 1277 , roots freedom in an affectio iustitiae distinct from our natural intellectual appetite for happiness. ${ }^{5}$ A broad-brush survey of Western thought might see this dissociation of freedom from our "natural dynamics", plus Ockham's "voluntarism", as profoundly affecting the way free will is perceived by many today. Arguably, Aquinas approach to issues of human agency is refreshingly pre-modern, and stimulates a nuanced, multivalent approach to the causes of human behaviour while allaying the fear that if our behaviour is caused, it cannot be free.

\footnotetext{
${ }^{1}$ References to Aquinas' Summa Theologiae are given in the format Part Question, Article. $1 \mathrm{a}=$ Prima Pars, $1 \mathrm{a} 2 \mathrm{ae}=$ Prima Secundae, etc.

${ }^{2} \mathrm{He}$ condemns usury in 2a2ae 78 (cf. De Malo 13,4) but in 78, 2 ad 5 recognises the legitimacy of making a profit (or loss) on a joint project in which one invests.

${ }^{3}$ Medieval Thought. A History of Western Philosophy, II. Oxford: OUP, 1997. 114-121.

${ }^{4}$ Bonaventure, Commentary on Book II of the Sentences, Dist. XXV, Part I, Qq. 3 \& 5.

${ }^{5}$ Thomas Williams, "How Scotus Separates Morality from Happiness." American Catholic Philosophical Quarterly 69 (1995) 425-445.
} 


\subsection{Free Decision Within a Complex Psyche}

The essential background to our discussion is Aquinas' acute awareness of the extreme complexity of the human psyche. The salient points are summarised here. ${ }^{6}$

\subsubsection{Abilities of a Complex Form of Life}

Aquinas uses nouns like "intellect" and "will". These "powers of soul" should not be reified as if they were departments in an office-block, each with its own decisionmaking power. A soul (of a plant, animal, or human) is a "form of life" unifying and animating the organism. Its powers (Aristotle's "potentialities") are abilities of the whole organism that result from its form of life. All living things are able to take in nutrition, to grow and to reproduce. Animals can also perceive and respond in subtle ways; human beings can perceive and respond both in "animal" and in specifically human ways.

\subsubsection{Animal Abilities to Interpret and Respond}

Some abilities are "active". Digestion works on the food we ingest; our "agent intellect" works on the rich and complex material in the imagination. Some abilities are "passive" in the technical sense of "receptive". The power of hearing is the animal's ability to be affected by sound so as to hear things; the "emotions" to be attracted by what it perceives as suitable, and repelled by what it perceives as noxious.

\footnotetext{
${ }^{6}$ Relevant texts include: 1a 77; 78; 79, 2-3; 80-86 (collected in R. Pasnau, Thomas Aquinas on Human Nature: A Study of Summa Theologiae Ia 75-89. Cambridge: CUP, 2002); 1a2ae 8-10; 22-23; 25. Secondary literature includes:

Diana Fritz Cates, Aquinas on the Emotions: A Religious-Ethical Inquiry. Washington DC: Georgetown University Press, 2009. Powers of soul are summarised on pp. 267-8.

R. Pasnau and C. Shields. The Philosophy of Aquinas. Boulder: Westview Press, 2004. Chapter 7 (on sensory and intellectual powers).

Nicholas E. Lombardo, The Logic of Desire: Aquinas on Emotion. Washington: Catholic University of America Press, 2010. Chapters 1-4.

Robert Miner, Thomas Aquinas on the Passions: A Study of Summa Theologiae 1a2ae 22-48. Cambridge: CUP, 2009.

${ }^{7}$ Passiones animae are basic patterns of attraction and repulsion. To call them "passions of soul" might imply too much passion to suit them all. To call them "emotions" risks importing a modern psychological concept, but does hint at the complex social life of the higher animals, and so remind us of what we share with them.
} 
Both kinds of ability have inbuilt dynamics, partly due to a shared nature, partly due to "individual nature" (e.g. the biochemistry of digestion is common to all humans, but some have more robust digestive systems than others).

Besides the five senses of touch, sight, etc., animals coordinate the sense-data received, and recall it via the "imagination". They also make sense of their world: by their "estimative sense" they perceive meanings like danger, and "affordances". 8 Hence they react to stimuli both internal (e.g. hunger) and external.

We share many abilities with other animals; much human consciousness is "animal consciousness".

\subsubsection{Limited Conscious Control; Pre-conscious "Acts"}

Some abilities are not under conscious control. We can decide when and what to eat, but not what the body does with what we eat.

Much coordination and interpretation of sense-data goes on pre-consciously; we become aware of plates and food, not "raw" patches of colour. ${ }^{9}$ Reactions, too, are partly pre-conscious: when charged by a bull we automatically feel fear. Both Aquinas and we attribute such activities to the brain, plus other bodily structures nerve impulses and hormones in our case, blood vessels and humours in Aquinas'.

\subsubsection{Rational Perception and Reaction}

Human beings have abilities other animals do not, namely intellectus and voluntas, "intellect" and "will".

The intellect is our ability to draw out and grasp universal truths, including those of applied sciences such as ethics-politics. We abstract universal concepts from particular instances located within space and time, and organise them into bodies of knowledge.

As the rational appetite the will is, in the technical sense, "passive" - the ability to be attracted by the good that reason perceives. It can "rise above" particular drives to "higher goods", even what Aquinas calls "universal good". I can resist hunger for the sake of political protest, or choose a painful medical procedure for the sake of future health.

\footnotetext{
${ }^{8}$ A term coined by J. J. Gibson. The Ecological Approach to Visual Perception. Boston: Houghton Mifflin Harcourt, 1979. 127.

${ }^{9}$ So good are we at seeing things, it is hard to become a good visual artist or cartoonist and isolate the shapes and patches of colour we need to focus on when painting or drawing.
} 


\subsubsection{Co-operation Between Intellect and Sensory Abilities, Between Will and Emotions}

Since "materiality" ties things down in space and time, Aquinas sees intellect and will as spiritual powers, not in themselves the functioning of bodily organs. ${ }^{10}$ This leads to a nuanced account of what external factors can influence them. However, our active use of concepts requires close cooperation between intellect, on the one hand, and the imagination and the estimative sense, on the other. We apply general knowledge to particular instances (e.g. a vet uses her knowledge of diseases in diagnosis). Even in abstract thought we make use of mental pictures, examples, implicit symbols, etc. Hence whatever affects brain functioning can affect our ability to think - sleep, drunkenness, brain injury, strong emotion... Both intellect and the senses are transformed by this close cooperation ${ }^{11}$ : we are rational in an animal way, and animal in a rational way. Our imagination can "play" with memories; our estimative sense is transformed into the "cogitative sense".

Will and emotions also influence each other. We are voluntary in an animal way, and animal in a voluntary way. Emotional "drives" can make things attractive or repugnant to us - to us as responsible beings. Will and emotions cooperate: many physical movements are under voluntary control, but it is through the emotions that the will puts them into effect, while our emotions wait upon the will's command before initiating deliberate movement. ${ }^{12}$

\subsubsection{Co-operation Between Intellect and Will in Free Decision}

A key point is that liberum arbitrium - sometimes translated as "free will", better translated as "free choice" or "free decision" - is achieved in two-way interaction between intellect and will. The cooperation between thinking and wanting is so close that Aristotle spoke both of "desirous reasoning" (orektikos nous) and "reasoning desire" (orexis dianoetikē) $)^{13}$; following NE 3.3 (1113a11) Aquinas considers "intellectual appetite" 14 better than "appetitive intellect". ${ }^{15}$ Thinking and

\footnotetext{
${ }^{10} 1 \mathrm{a}, 75,2 ; 1 \mathrm{a} 2 \mathrm{ae} 9,5$.

${ }^{11}$ Candace Vogler, "The Intellectual Animal." A lecture delivered at Blackfriars, Oxford, on 2 March, 2017. Available https://www.youtube.com/watch?v=4IhNm1fa8GE. New Blackfriars (forthcoming).

${ }^{12} 1 \mathrm{a} 81,3$.

${ }^{13}$ Nicomachean Ethics (NE) 6.2 (1139b4).

${ }^{14}$ To call the will "intellectual appetite" does not mean it is always "highbrow". I have an intellectual appetite for dark chocolate, since I know I will enjoy it.
}

${ }^{15} 1 \mathrm{a} 83,3-4$. 
wanting are so entangled that Mark Jordan speaks of "the untellable circlings of will and intellect". ${ }^{16}$

\subsubsection{Development of Habits and Virtues}

Many abilities are "open-ended" and can be "moulded" further by training and practice. We can "shape" our intellects with concepts of economics or engineering. We can be trained as children, or train ourselves later, to enjoy adult food. ${ }^{17}$ This channelling of an ability is a "habit", not in the sense of a nervous tic that takes us over, but rather like a learned skill we can deploy. A virtue, a good habit, is an enabling life-skill. A bad habit, a vice, means some aspect of our behaviour is habitually mis-directed. ${ }^{18}$

We can develop "intellectual virtues", "strengths of mind", that empower us to use our minds readily in theoretical and practical ways. ${ }^{19}$ These do not make us good people. We can also develop "moral virtues", "strengths of character", that bring our emotions and wills into harmony with right reason, so that "by second nature" we desire what is truly good, truly fulfilling, and live it out with readiness and a sense of fulfilment. ${ }^{20}$ Moral virtues are deployed by the intellectual virtue prudentia ("prudence" or, better, "good moral sense") and in turn support it, so that, unlike sciences and crafts, it is inseparable from being good.

\subsubsection{Limited Conscious Self-Awareness}

Consciousness is not a core concept for Aquinas: animals are conscious in various and shifting ways, and so are we. Being conscious of toothache makes it difficult to be conscious of other things.

In particular, we are not conscious of the whole "contents" of our intellects or of our wills. The human psyche is not geared to introspection. I am not consciously aware of concepts I have learned until some situation prompts me to call upon them. Nor am I fully aware of the priorities I hold, the "habits" that "structure" my will, until they result in acts of will. ${ }^{21}$ Both concepts and willed choices emerge from "the

\footnotetext{
${ }^{16}$ Teaching Bodies: Moral Formation in the Summa of Thomas Aquinas. New York: Fordham University Press, 2017. 102.

${ }^{17}$ This reminds us to hear "passive ability" in a nuanced way.

${ }^{18}$ Habits are treated in 1a2ae 49-54; virtue in 55-56.

${ }^{19} 1 \mathrm{a} 2 \mathrm{ae} 57$.

${ }^{20} 1 \mathrm{a} 2 \mathrm{ae}$ 57-61. For Aristotle and Aquinas, reason takes charge of emotions in "political", not a "despotic" way (1a 81, 3 ad 2; 1a2ae 17, 7): emotions have dynamics we must work with sympathetically.

${ }^{21}$ 1a 87; 1a2ae 112, 5.
} 
habitual retention of knowledge and love". ${ }^{22}$ We sometimes discover our wants; I may surprise myself by what I do - it may be different from what I supposed I wanted to do! ${ }^{23}$

\subsubsection{Influences Upon "Embedded" Free Decision}

It should now be obvious that internal and external factors affecting our bodies affect both our outward senses and our imaginations and emotions. Through them they can impinge on our intellects and wills, both because thinking draws on and cooperates with the senses, and because we can perceive our internal state (of hunger, health, emotion, etc.) to some extent. Our free decisions involve perceptions and motives at various levels of our psyche, many of which have been shaped by past behaviour and interactions.

The human will does not spring into being as part of a fully-formed, selfsufficient, adult psyche able to select its choices within a landscape it surveys. We come into being (a) needing to grow towards the use of reason, (b) "embedded" in a biological and psycho-social situation on which we are highly dependent - and to which we are vulnerable - and (c) with both intellect and will as "blank slates"24 even though they have intrinsic dynamics towards the true and the good. In our growth to maturity we remain highly dependent on human interaction; in developing virtue we must deal sympathetically and practically with the effects nature, nurture and earlier decisions have had on our emotions.

At no stage is the human will an "unmoved first mover", spontaneously and independently bringing an act of will into being. ${ }^{25}$ It is true that while Aquinas saw external factors as able to influence our senses and emotions, and to some extent our intellects, he held that no external agent could directly influence the human will. However, he insisted that whenever any human being's will acts, it is attracted into "act" by God as the Unmoved First Mover. For we are "embedded in God" who is in fact within the will, (a) as the Source of all being who holds the will and its "acts" in being, and (b) as the Infinite Good, the ultimate attractive Goal, who attracts our will into seeking good. ${ }^{26}$ Further, by Grace God can "enlarge our hearts" (Psalm 119:32) to embrace him as our Friend and to liberate us from false thinking

\footnotetext{
${ }^{22} 1 \mathrm{a} 93,8$.

${ }^{23}$ Nicely described by Gareth Moore, The Body in Context: Sex and Catholicism. London: Continuum, 2001. 16.

${ }^{24} 1 \mathrm{a} 84,3$.

${ }^{25} 1 \mathrm{a} 2 \mathrm{ae} 9,4$.

${ }^{26} 1 \mathrm{a} 2 \mathrm{ae} 9,6$. Bonaventure, too, denied that a liberum arbitrium "presides over" intellect and will, initiating their directions of thinking and loving. Commentary on Book II of the Sentences, D. XXV, Part I, Q. 2.
} 
and willing. Grace is typically mediated through the Sacraments God gave to the Christian community. ${ }^{27}$

This outline of the contexts of our free decisions warns us not to expect a simple - let alone a reductionist - analysis of what might make for predictability in human behaviour.

\subsection{Explicable But Open-Ended Freedom}

To see the will as the ability to be attracted by the good perceived by reason is very different from a "voluntarism" which (to some extent caricatured) sees the will as a free-floating, pro-active, arbitrary deciding power surveying a landscape of options and saying, without motive or other such constraint, "I shall have X today." This would make an act of will the mental equivalent of flipping a coin. Pinckaers labels the resultant view of freedom "freedom of indifference": the will is faced with a range of options "on an even field" ${ }^{28}$ Arguably, it lies behind the presumption that increasing people's freedom is a matter of maximising their choices. Modern discussions of freedom, and Benjamin Libet's experiments, ${ }^{29}$ do often focus on such arbitrary choices. If individual choices were purely arbitrary, the resulting randomness might translate up into statistical predictability of behaviour. If, as Libet's experiments have suggested to some, choices are made prior to conscious awareness, they might become predictable once the biochemical or other factors that precipitate them are discovered.

However, investigations of arbitrary, random choices do not engage with Aquinas' account of truly human, deliberate choice, for he would label unthinking choices "acts of human beings"; by contrast, "human acts" engage us as rational, responsible, goal-seeking agents. ${ }^{30}$ They are free by what Pinckaers terms "freedom for excellence", ${ }^{31}$ that is, by "responsible ownership" of decisions. Motives and reasons do not constrain us, but contribute to freedom: if I can explain my behaviour, this means I have owned it by reflection on what is good for me, i.e. what on truly contributes to my well-being.

This view of freedom goes with a "metaphysics of morals" in which characters, decisions and actions are susceptible of more or less goodness; and insofar as they have more goodness, they have more being or reality, more integrity and truth. ${ }^{32}$ Hence freedom is susceptible of varying degrees. If our hierarchy of values corresponds to

\footnotetext{
${ }^{27} 1 \mathrm{a} 2 \mathrm{ae} 62 ; 109-112 ; 3 \mathrm{a} 62$.

${ }^{28}$ Servais Pinckaers, The Sources of Christian Ethics. Edinburgh: T \& T Clark, 1995. Chapter 14.

${ }^{29}$ Helpfully described and critiqued at http://www.informationphilosopher.com/freedom/libet_ experiments.html

${ }^{30}$ 1a2ae 1, 1. As Mary Midgley remarked, "Randomness would not be freedom." Wickedness: A Philosophical Essay. London: Routledge \& Kegan Paul, 1984. 111.

${ }^{31}$ The Sources of Christian Ethics, Chapter 15.

${ }^{32} 1 \mathrm{a} 2$ ae 18,1 ; "deep down", truth and unity "coalesce" with goodness and being: 1a 5, 1; 11, 1; 16, 3 .
} 
the truth of things, and if we have the integrity to pursue wholeheartedly what is really good for us, we are the more free. Truly free behaviour is more rationally explicable than less free behaviour - explicable in terms of the goals it is happymaking for human beings to pursue.

The causality involved in truly human behaviour is final causality. It operates in a way appropriate to rational agents who act in the light of goals held with (ideally) increasing degrees of coherence. ${ }^{33}$

Insofar we behave in a human way, any predictability of our behaviour will not result from the statistics of random choices, or from mere biochemistry, but from the rational explicability of responsible choices. Given our psyche's "embedded complexity", one might hope to predict what an individual would choose in a given situation knowing her "personal chemistry", her acquired patterns of behaviour, and her account of her motives, her goals. However, besides our susceptibility to outside influences, there are (a) a "cascade effect" in "the untellable circlings of will and intellect" which seems to limit the predictability of particular choices, especially ones that do not engage any portentous moral judgment, and (b) elements of mystery in the human psyche:

- The will has an inner dynamic towards "the good" in the sense of beatitudo (equivalent to Aristotle's eudaimonia: happiness, flourishing, fulfilment). This is not a matter of free choice; we want to be happy voluntarily, but cannot choose whether or not to want to be happy. ${ }^{34}$

- This inbuilt dynamic responds to a prior apprehension of "the good", and of the good as to be pursued, built into the intellect, which Aquinas calls synderesis. ${ }^{35}$

- Our drive to happiness energises reflection on what will make us happy, which we thereby find attractive. We can perceive power, pleasure or wealth, etc., as our chief priority - or God. ${ }^{36}$ In an important sense people must make this basic decision once they have the use of reason. ${ }^{37}$ It can be an implicit decision; and we can change it. We can even change our priority from God to something else. ${ }^{38}$

- In the pursuit of more basic ends, we choose means to them; this is where free decision comes in. ${ }^{39}$

- Free decision is not needed when there is only one obvious means to a goal. ${ }^{40}$

- In selecting a means, we exercise free choice by comparing contingents. Choice is free because our thinking is open-ended: we can note advantages and disadvantages of various means, and (since decisions cannot be deferred indefinitely)

\footnotetext{
${ }^{33} 1$ a 60,$2 ; 1$ a2ae 1,1 \& 6; 6, 1 .

${ }^{34} 1$ a 82,$1 ; 1$ a 2 ae $10,1$.

${ }^{35}$ 1a $7912 ; 82,4$ ad 3; 1a2ae 94, 2.

${ }^{36} 1 \mathrm{a} 2 \mathrm{ae} 2$ details these possibilities.

${ }^{37} 1 \mathrm{a} 2 \mathrm{ae} 89,6$.

${ }^{38}$ Turning against God is rarely explicit; more often it is implied by some serious sin: 2a2ae 34, 2 .

${ }^{39} 1$ a 82,$2 ; 1$ a 2 ae $8,2-3 ; 14,2$.

${ }^{40} 1 \mathrm{a} 2 \mathrm{ae} 10,2$.
} 
a certain indeterminateness and spontaneity operates here - within the time available we are not determined to choose a particular means. ${ }^{41}$ We can fail to take something important into consideration, and failure can be voluntary. ${ }^{42}$

- Having made a careful decision, we can still fail to carry it through owing to factors such as fear and laziness. That is, we can fail to follow our conscience. This failure, too, is voluntary. ${ }^{43}$

An "economic" example illustrates how, in this "cascade", a means becomes an end for a subordinate decision, and how difficulties at lower levels can prompt rethinking at higher levels. If a concert is arranged in Manchester, it might be predicted that many people will attend, so that special train services are laid on. If my musical interests make attending the concert a "medium-sized" goal, I investigate means to that end (e.g. train travel) and, with those means acting as a subordinate end, I weigh up further means (buying a ticket on a chartered train, an advancepurchase ticket on a specified train, or an open return). Which I choose depends on how I perceive the alternatives (flexible timing versus a cheaper fare; a quiet journey versus the "buzz" of a chartered train). Maybe no means is open (there are no advance-purchase tickets; I can't afford a flexible ticket; I cannot cope with the crush on a chartered train), and I give up my "medium-sized" goal. A means might be open if I sacrifice a higher good: I could steal the money - then my basic goal comes into question, since theft is sinful, and (hopefully) I still give up the mediumsized goal. I may well not weigh up every option - but failing to consider a certain option may be a voluntary mistake (e.g. I don't notice a very cheap plane fare, either because I couldn't have realised a plane service had been established, or because I knew there might be one but didn't look into it). Further, while pursuing the mediumsized goal, I might culpably fail to think of every relevant thing, and so, culpably, fail to respect a greater goal (e.g. I promised to meet an important deadline, and going to Manchester makes me break my promise).

Clearly, such thinking does not have the compelling force of a geometrical proof. Even if my friends could have predicted I would try to attend the concert, and even if the train company correctly predicted the number travelling by train, my decision was not determined. In retrospect I will be able to explain my actions, but in doing so I may realise I made bad decisions, or failed to execute good ones as I should. Rationality is compatible with elements of spontaneity, mystery and openendedness; open-endedness is multiplied by the complexities both of the psyche, and of the situations among whose contingencies we negotiate practical decisions.

Many decisions in regard to the concert entailed no disobeying a serious moral law, hence one could not determine whether I would attend it simply on the basis of my goodness. Yet, Aquinas holds, no concrete human act is morally indifferent. Buying a first-class ticket might be no sin, but it would be "more perfect" to buy a cheaper ticket and give money to charity, and yet more perfect to miss the concert

\footnotetext{
${ }^{41} 1 \mathrm{a} 2 \mathrm{ae} 13,5-6 ; 14,2,3$ \& 6.

${ }^{42} 1 \mathrm{a} 2 \mathrm{ae} 6,3$ \& 8 .

${ }^{43} 1 \mathrm{a} 2 \mathrm{ae} 19,5$, cf. 6, 6-7.
} 
and spend the time working in a hospice. ${ }^{44} \mathrm{~A}$ great deal must fall into place for human decisions to be made, and yet more if our characters and behaviour are to have perfect integrity and truth, and thus perfect goodness.

\subsection{In Humanity's Ideal State, Would Behaviour Be Predictable?}

On Aquinas' account of the Fall, the first human beings were endowed with gifts such as moral integrity; if they had not sinned, all human beings would have been born with those gifts. ${ }^{45}$ Children would still have grown towards the full use of reason, and acquired knowledge, ${ }^{46}$ but their wills would have been formed by Charity ${ }^{47}$ Aquinas sometimes performs a "thought-experiment" about what an unfallen state would have been like to help distinguish what is natural to us both from what is the result of the Fall, and from what (being supernatural ${ }^{48}$ ) must always be God-given. ${ }^{49}$

Some of Aquinas' speculations have implications for the predictability of behaviour in an ideal state. People would naturally have behaved sensibly, as individuals and as communities, avoiding anything harmful and practising good citizenship..$^{50}$ They would have engaged in practical reasoning because of the complexities of the world and of society. People would have been unequal: owing to shifting patterns of the stars, and variations in climate, some would have been stronger and wiser than others, though there would have been no birth defects.$^{51}$ By free choice, some would have advanced in knowledge and justice more than others. ${ }^{52}$ There would have been no slavery; people would have been governed for their own and for the common good, not used. ${ }^{53}$ Within the context of good citizenship, people would have made varying choices about careers to pursue, where to live, whom to marry - "personal" but not irrational choices. It would have been possible to count on a balanced pattern of social roles. Lawgivers' decisions about how to apply the Natural Law to particular circumstances, and leaders' policies, would have been sensible yet also "prudential",

\footnotetext{
${ }^{44}$ No act actually performed is morally indifferent (1a2ae 18, 9), but Aquinas distinguishes precepts from counsels $(1 \mathrm{a} 2 \mathrm{ae} 108,4)$ : we are not obliged under pain of sin to follow counsels.

${ }^{45}$ 1a $95 ; 100,1$.

${ }^{46} 1 \mathrm{a} 101$.

${ }^{47}$ Charity is a love for God that empowers a journey into him: 1a2ae 62.

${ }^{48}$ The "supernatural" is not the "spooky", but the divine. Forgiving enemies is more supernatural than levitating.

${ }^{49}$ Besides 1a 94-101, see 1a2ae 109, 1-5.

${ }^{50}$ Hinted at in 1a 97, 2 ad 4.

${ }^{51} 1 \mathrm{a} 96,3$.

${ }^{52} \mathrm{Ib}$. This affirms the claim that, without $\sin$, people can choose among more and less perfect options.

${ }^{53}$ 1a $96,4$.
} 
not determined by rigid reasoning process such as geometry uses ${ }^{54} \mathrm{Clearly}$, an ideal society would be anything but a uniform, regimented army. An unfallen race would be more interesting, vibrant and vital - because more human - than a fallen one. People would have been free for excellence.

The thought-experiment reassures us that variety ${ }^{55}$ and vibrancy are natural. A fallen world's warped perspective might suggest that vice is interesting and virtue boring, but the opposite is true; this meshes with Aristotle's conviction that while virtue is a mean between extremes, it is not mediocre, ${ }^{56}$ and with Aquinas' implication that friendship with God grows into an "exhilarating resonance". ${ }^{57}$ In the world as it is, people often are liberated from some effects of the Fall by God-given virtues and, I should argue, by the ways we help each other acquire virtues. ${ }^{58}$ While we can predict that virtuous people will behave well, good citizenship does not make them clones of each other. Human variety, the open-endedness of practical thinking, and the strange beauty of grace, mean that virtuous people's choices will often be more interesting and various than the dull and sadly predictable behaviour of people tied to various vices.

\subsection{Fallen, Vulnerable Humanity's Predictability}

For Aquinas, the Fall deprived us of supernatural gifts such as Charity; these are restored through Christ. Along with these gifts, others, that came to be called "preternatural", were also lost ${ }^{59}$; in God's providence, these are not restored in full in this life. ${ }^{60}$ They remedied the physical and psychological vulnerability that are natural to us as complex and interdependent, hence their loss has wounded us: our darkened intellect no longer has a firm grasp of the principles of moral reasoning, a grasp that actively pervades our practical decisions; our will is weakened, and our emotions often run ahead of reason, or impede it. ${ }^{61}$ There remain natural, and basically good, dynamics within our faculties ${ }^{62}$; Mary Midgley brought out - in a way similar to Aquinas - the dangers attendant on failing to integrate these with

\footnotetext{
${ }^{54} 1 \mathrm{a} 2 \mathrm{ae} 96,1$ ad 3. Cf. the need for counsel, circumspection and caution: 1a2ae 14, 1; 2a2ae 49, $7-8$.

${ }^{55}$ Naturally, in a fallen world there can also be immoral variations in preference.

${ }^{56}$ Nicomachean Ethics 2, 6 (1107a6-8).

${ }^{57}$ Andrew Pinsent, The Second Person Perspective in Aquinas's Ethics: Virtues and Gifts. London: Routledge, 2012. 96-98.

${ }^{58}$ To recognise how moral education, like medical techniques, can alleviate some effects of the Fall is not to deny our dependence on God for the restoration of Charity, and for total healing in the final resurrection.

${ }^{59} 1 \mathrm{a} 2 \mathrm{ae} 82 ; 2 \mathrm{a} 2 \mathrm{ae} 164$. Moral/psychological integrity and immunity from sickness are "preternatural" since they could conceivably exist in people who loved God as Creator, but to whom he had not offered the supernatural goal of sharing his bliss.

${ }^{60} 3 \mathrm{a} 69,3$.

${ }^{61} 1 \mathrm{a} 2 \mathrm{ae} 17,7 ; 24,3$ ad $1 ; 85,3$ \& 5-6.

${ }^{62} 1 \mathrm{a} 2 \mathrm{ae} 24,2 \& 4 ; 63,1$.
} 
rational considerations. ${ }^{63}$ It is difficult to attend to all relevant aspects of a situation; and to carry through our decisions we must often overcome laziness, fear, or disordered desire.

Aquinas affirmed Aristotle's account of how the training of children, good laws, the advice of friends, and personal practice, promote "acquired" virtues that restore some degree of moral integrity ${ }^{64}$ All this is liberating, not coercive. It involves practical ways of dealing with emotional difficulties; for example sadness may require companionship, sleep, bathing, legitimate pleasures, or cathartic weeping ${ }^{65}$ rather than "pulling yourself together" - we would add suitable drugs, when medically indicated, to the list.

Unless they are so strong as to dement us, emotions cannot override freedom, but they can affect it. ${ }^{66}$ It is difficult to achieve a moral integrity in which emotions enhance a rational behaviour personally "owned". Since vice, in which both reason and the affective powers cooperate in evil, is unnatural, ${ }^{67}$ thorough-going vice is relatively rare. Aquinas seems to share Aristotle's suspicion that many people are neither virtuous nor vicious, but "controlled" or "uncontrolled"68: if, for example, the presence of onlookers shames them, they do what is good "through gritted teeth"; sometimes they do evil, but "with a bad conscience". Many people follow their emotions, and do not make the effort to rise above them ${ }^{69}$; they often perceive lesser goods that are easy and immediate as preferable to greater goods that in principle they know are better, but which are more demanding and distant. ${ }^{70}$

We can expect most people to tend to a mediocre level of morality in which they behave rationally enough, at least when "controlled", and especially as regards the most basic principles of moral/practical reasoning that remain innate and potent. ${ }^{71}$ We can predict that most humans will make efforts to keep themselves alive, will beget children and care for them, will be social, and will worship God (or "gods"). ${ }^{72}$ In a reasonably well-run society, we can count on most people obeying laws that carry sanctions and listening to persuasive advice; for example, if certain foodstuffs are lauded as healthy by respected authorities, people will buy them, unless they are so costly that doing so would deprive them of basic necessities. If certain substances are known to be dangerous, or are prohibitively expensive, or their use carries severe sanctions, few people will be so irrational as to purchase them.

At the same time, a failure to develop full rational control of their lives will leave many people vulnerable, not only to emotional drives, but also to bad laws and cor-

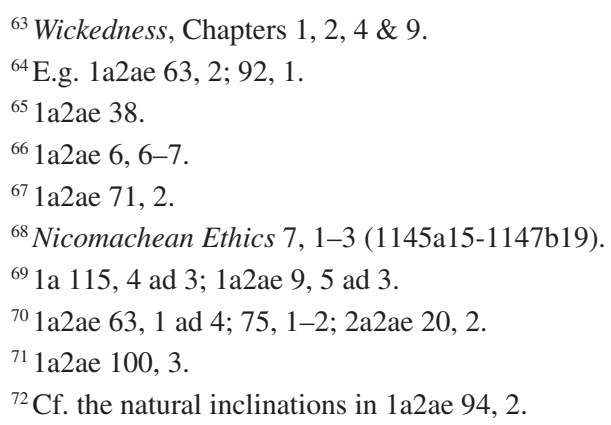


rupt customs, to threats and peer-pressure. Human and God-given courage, and often the support of friends, empower some people to resist, but coercive rulers can often count on a large proportion of people yielding to even unpopular policies.

If many people do not rise above their emotions, personal temperaments (due to nature and nurture) will lead to some predictability in their behaviour once we know them and their backgrounds. We will examine below the factors Aquinas saw as influencing personal temperament. It seems he would not reject a statistical predictability resulting from the proportion of temperaments that is likely, or observable, owing to genetic, geographical and social factors. ${ }^{73}$

To those he graces, God imparts a panoply of virtues that gradually reintegrate our psyche, liberating us from Original and actual sin, ${ }^{74}$ though in most cases moral reintegration is partial this side of the grave. Aquinas does not predict that those whom God graces will regularly behave in ways that strike society as odd: Charity does not typically snatch people away from family commitments, but typically affirms, purifies, orders, divinises and widens natural affections. ${ }^{75}$ All the same, in a fallen world there is a war on against evil, so that Charity always leads to some dramatic gestures (e.g. fasting) ${ }^{76}$ and makes people wary of following the herd uncritically. In some cases it leads people to adopt odd forms of life, e.g. by making religious vows. ${ }^{77}$ In the Middle Ages this had an immense, and arguably beneficial, economic effect on society. ${ }^{78}$ It would be interesting to assess the current impact of ways in which devotion prompts people to stand out from the herd.

\subsection{Factors Causing Predictability, Especially of the Majority}

When reason is truly free, our decisions have a vitality that sometimes make us stand out from the herd, and we have the insight and integrity to assess laws, peerpressure and emotional urges rather than blindly follow them. But Aquinas held that many people do not take full rational control of their lives, with the result that factors operating at less personal levels to influence their emotions and perceptions will affect their behaviour unduly, and often in ways that make for some predictability.

\footnotetext{
${ }^{73}$ Aquinas saw individual chance variations as translating up into a statistical pattern in at least one area: it is by chance that a child is conceived male or female, but in this way "Nature" designedly produces the same number of males and females overall (1a 92, 1 ad 1).

$741 \mathrm{a} 2 \mathrm{ae} 62 ; 63,3$.

${ }^{75} 2 \mathrm{a} 2 \mathrm{ae} 25,6$ \& 8-9; 26, 6-12.

${ }^{76} 1 \mathrm{a} 2 \mathrm{ae} 63,4$.

${ }^{77} 2 \mathrm{a} 2 \mathrm{ae} 186$.

${ }^{78}$ The growth of Cistercian life reclaimed land for farming; monasteries were empowering centres of local economy.
} 


\subsubsection{Heavenly Bodies}

Following contemporary astronomy, Aquinas saw the heavenly bodies as having an immense influence on what happens here below: no reproduction was possible without an input of "energy" from the Sun. Their shifting patterns allowed the ongoing variety of earthly events, but - owing to the chance coincidence of causes, and the varying dispositions of matter - without imposing determinism on them. ${ }^{79}$ For human beings, (a) the pattern of the heavenly bodies at conception influenced someone's "personal chemistry", ${ }^{80}$ (b) the heavenly bodies had an on-going effect on our bodily organs, and through them on our imagination and emotions, and (c) thereby, indirectly, the heavenly bodies could influence our intellect and, to a lesser extent, attract our will. However, they could not force the human will so as to cause human acts, because the will does not necessarily follow the inclinations of the lower appetites. ${ }^{81}$ Nevertheless, since many people do not make the effort to rise above their emotions, particular patterns of the heavenly bodies could, predictably, provoke "mass movements" through their influence on people's imaginations and emotions. Hence astrologers could make correct predictions of events like wars. ${ }^{82}$

This view, though incorrect, did imply a recognition of (i) "personal chemistry", the propensities to virtue or vice in us at birth; (ii) our susceptibility to physical influences; and (iii) the possibility that mass movements might be explicable. Aquinas would not reject modern studies of our susceptibility to environmental, subconscious, pre-conscious and "psychological" influences. ${ }^{83}$

\subsubsection{Inheritance}

Aquinas accepted that human beings can inherit bodily defects, and characteristics like athletic ability or mental agility, but not personally acquired skills. ${ }^{84}$ Since he attributed propensities to particular virtues or vices to innate bodily dispositions, he presumably thought these were heritable, and would not be averse to studies of how character traits and behaviours that are not consciously chosen can be inherited. If patterns of behaviour do run in families, the relative proportions of patterns in a stable community might last for many generations. Modern science attributes to genetic factors a great influence over people's "character", in a sense replacing Aquinas' account of the heavenly bodies' real and natural causal power.

\footnotetext{
${ }^{79}$ la 115,3 ad $2, \& 6$.

${ }^{80}$ For being born with certain propensities, see $1 \mathrm{a} 2 \mathrm{ae} 50,1 ; 63,1$; for the influence of the heavenly bodies, 1a 96,3 .

${ }^{81}$ la 115,4 .

${ }^{82} \mathrm{Ib}$. ad 3.

${ }^{83}$ For some time, advertisers have used subliminal techniques; the influence of environmental factors, including scents, on people's behaviour in shops has been widely studied.

${ }^{84} 1 \mathrm{a} 2 \mathrm{ae} 81,1-2$.
} 
Aquinas' recognition of environmental and social factors, of personal choice, and of God's grace, reminds us not to rely only on genetics when investigating what contributes to people's characters. ${ }^{85}$

\subsubsection{Climate}

Aquinas recognised climatic factors ${ }^{86}$; he might well not be surprised by seasonal affective disorder, and might expect the climate of a region to have some predictable influence on patterns of behaviour there.

\subsubsection{Corrupt or Worthy Customs}

Current sociology would probably accord more influence than Aquinas did to cultural factors, to society's "mood" and presuppositions, and would analyse more deeply why many people follow these. But Aquinas did hold that, while in some sense the basic and obvious points of the Natural Law are built into everyone, we are still vulnerable to corrupt customs which can obscure even things that should be obvious.$^{87}$ On the other hand, worthy customs can be a force for good behaviour and hence character-formation.

\subsubsection{Coercive Law}

In a fallen world, it is not easy to work out the fine details of the Natural Law; it requires a long-term effort on the part of the wise. ${ }^{88}$ Governments have the task of applying the Natural Law to local circumstances, of revising laws, and of granting dispensations justly. ${ }^{89}$ This requires a special kind of prudentia. ${ }^{90}$ It can be assumed that most people will follow law, either because they are good, or because it carries sanctions. ${ }^{91}$ Given the power of corrupt customs, Aquinas might not be surprised to find that in certain countries and cultures honesty in filling in tax returns is easier to count on than in others. He would presumably agree that, out of fear, many people

\footnotetext{
${ }^{85}$ Good science is non-reductive in this regard; it also recognises "Lamarckian" as well as "Mendelian" inheritance, but judiciously: Edith Heard and Robert A. Martienssen, “Transgenerational Epigenetic Inheritance: Myths and Mechanisms." Cell 157 (2014) 95-109.

${ }^{86} 1 \mathrm{a} 96,3$

${ }^{87} 1 \mathrm{a} 2 \mathrm{ae} 94,4 \& 6$

${ }^{88} 1 \mathrm{a} 2 \mathrm{ae} 100,1$.

${ }^{89} 1 \mathrm{a} 2 \mathrm{ae} 91,3 ; 95,1-2 ; 97,4$.

${ }^{90} 2 \mathrm{a} 2 \mathrm{ae} 47,10-11 ; 50,1$.

${ }^{91} 1 \mathrm{a} 2 \mathrm{ae} 92 ; 96,5$.
} 
follow laws that should be disobeyed ${ }^{92}$; we might want to explore more deeply what instincts lead people to do what they are told even when it is questionable or unpopular.

If the proportion of people who will follow a particular kind of law can be estimated for a particular society, on the basis of observation, those who practise economics, as well as legislators and policy-makers, can rely on this estimate. It would be useful to study the power of law to influence not only behaviour, but also moral perceptions; this is probably greater than is often supposed. ${ }^{93}$

\subsubsection{Persuasion and Protreptic}

Perceptions and desires can be moulded by persuasion and protreptic on the part of preachers, teachers, experts and officials. Aquinas practised protreptic ${ }^{94}$; his work was embedded in a Scriptural and Liturgical system of moral formation in which Christ was the great moral Exemplar. ${ }^{95}$ While modern psychology has studied more deeply children's development in its social context, and phenomena such as peerpressure, Aquinas would expect educational systems to have a predictable effect on people's behaviour.

One thing he might have difficulty with is brainwashing, since the behaviour of a brain-washed person "comes from within" and so seems to count as voluntary ${ }^{96}$; yet it is imposed from without, against the person's deliberate choice.

\subsection{Angels, Demons and Grace: Causes of Unpredictability?}

Thus in the Mediaeval trio "the World, the Flesh and the Devil", ${ }^{97}$ the world (social influences) and the flesh (the emotions, and genetic and environmental factors that influence them) largely make for predictability. For Aquinas, angels and demons also had a strong influence. ${ }^{98} \mathrm{He}$ saw them as affecting many physical occurrences

\footnotetext{
${ }^{92} \mathrm{He}$ has a nuanced view about whether bad laws should be obeyed: 1a2ae 96, 4 .

${ }^{93}$ E.g. to what extent did the Abortion Law make people see abortion as a morally legitimate option? One such study is Yuval Feldman and Oren Perez, "How Law Changes the Environmental Mind: An Experimental Study of the Effect of Legal Norms on Moral Perceptions and Civic Enforcement." Journal of Law and Society 36 (2009) 501-535.

${ }^{94}$ Adam Eitel, "The Protreptic of Summa Theologiae I-II, qq. 1-5." The Thomist 81 (2017) 183-212.

${ }^{95}$ Mark Jordan, Teaching Bodies. Chapters 1-4.

${ }^{96} 1 \mathrm{a} 2 \mathrm{ae} 6,4$.

${ }^{97} 1 \mathrm{a} 114,1$ ad 3.

${ }^{98}$ 1a 111-114. Angels' existence seemed obvious, since the heavenly bodies kept revolving because angels pushed them: experience suggested that when you stop pushing, things grind to a halt. The fourteenth century saw develop the concept of a temporary impulse, later replaced by the concept of inertia: James A. Weisheipl, Nature and Motion in the Middle Ages. Washington DC: Catholic University of America Press, 1985. 31-73.
} 
on earth; they could move humours in the body and influence imaginations and emotions, and so could present us persuasively with ideas. Angels could not, directly, put abstract concepts into our intellects, but they could strengthen them. ${ }^{99}$ Our dependence on the imagination both for forming and for employing concepts meant our mental susceptibility to angelic influence was marked; however, as with the heavenly bodies, the human will was open to God alone - no angel could "get inside" it. ${ }^{100}$ Rebel angels - demons - could also influence us, towards evil, but only under God's providential permission. ${ }^{101}$ They could not influence the human will directly, any more than could the good angels or the heavenly bodies.

A healthy aspect of Aquinas' account of moral evil is his resistance to the idea that all sins are due to the devil; often enough they are due to "the world" or "the flesh", or simply to the mysterious lability of a created will. ${ }^{102}$ Many modern Christians accept the influence of angels and demons, but Aquinas remains a valuable conversation partner for people who do not: he was not reluctant to recognise many forms of vulnerability to non-voluntary, pre-conscious interior and exterior influences, and would not rule out in principle psychological accounts of mental and moral problems. If we do accept the existence of angels and demons, we should (with Aquinas) recognise that they can only work on and with the human psychological material accessible to their influence; we would expect them as a rule to do so in subtle ways.

The influence of angels and demons might result in unpredictability: one could imagine that (under God's Providence!) demons might incite a people to evil in a way that could not have been foreseen - or (sent by God) good angels might excite a good social atmosphere. Recent centuries have seen more than their fair share of mass hysteria, genocidal hatred, revolutionary fervour that leads to a reign of terror, and similar events that might be labelled "demonic" even by people who do not believe in demons. We have also seen strikingly beneficent social movements; the fall of apartheid without a blood-bath springs to mind. If we believe in angels, we might surmise they have a role in such events, under divine providence, and without prejudice to the priority of God's grace which alone can be at work within the human will. ${ }^{103}$

Since angels and demons only work on and with the human psychological material accessible to their influence, their role might be, if not predictable, at least interpretable in retrospect. Certain studies have suggested that political history moves in stages which include times of marked vulnerability. ${ }^{104}$ If so, and someone like Hitler comes on the scene at such a time, disaster can happen "out of the blue";

\footnotetext{
${ }^{99} 1 \mathrm{a} 111,1$ \& 3-4.

${ }^{100} 1 \mathrm{a} 111,2$.

${ }^{101}$ 1a $114,1$.

${ }^{102}$ 1a 63,$1 ; 114,3$. Moral evil, as intrinsically "messy", has neither a fully satisfying rational explanation, nor a unitary cause: $1 \mathrm{a} 2 \mathrm{ae} 73,1$.

${ }^{103}$ 1a 105,4 ; 1 a2ae $9,6$.

${ }^{104}$ The studies were helpfully and critically reviewed by Frances Hagopian, "Political Development, Revisited." Comparative Political Studies 33 (2000) 880-911.
} 
if someone with a charisma for good is providentially granted (e.g. Martin Luther King, Nelson Mandela), un-hoped-for improvements take place. In such periods the influence of angels and demons might be especially marked as they work on and with natural liabilities, including our susceptibility to "public opinion" as enunciated (or manipulated) by the media, by demagogues - or by orators of truth and goodness.

Finally, we must recall that God's grace, "enlarging our hearts", is at work. Typically, it does not cut across the natural, but brings it to perfection in a way that promotes moral beauty. ${ }^{105}$ Hence it does not annul the natural elements of predictability and unpredictability we have examined. The striking things some of God's friends are inspired to do are not its most usual activities. Grace may be doing more than we realise - we dare not tame or corral it - to cause much more to go right in human behaviour than would go right if such a complex creature were left to its natural resources alone. On the other hand, it would not be true to Aquinas to deny the value of those resources which, being natural, we retain in a fallen world.

\subsection{Conclusion}

Aquinas' pre-modern view of the complexity of human psychology, of the decisionmaking process, and of the situations calling for decisions, has invited us to reflect on the nature of freedom and on the forms and causes of predictability. Freedom involves self-possession, not randomness of decisions, hence the statistics of randomness are not the correct way to approach human predictability. Final causality operates, in a distinctively human way, so that we can give a rational account of any free act of ours, even if in doing so we come to realise flaws in our thinking. At a first level of analysis, we might expect our inner dynamics towards truth and goodness to lead to predictability: people will tend to do the sensible thing. This is the case to some extent: most people make adequate provision for themselves and their families through work and household management; they generally follow law and custom. In an ideal world, they would do so through good citizenship; in a fallen world it is either through good citizenship or through fear of sanctions. People are also liable to be misled (in thinking and behaving) through corrupt laws and customs. However, natural human variety means that personal choices would make an unfallen society vibrant with variety; in a fallen world, grace leads God's close friends to buck the social trend in at least some ways.

Much of our psyche is responsive rather than pro-active; much of what goes on in it is pre-conscious. Free decisions involve interaction between thinking and wanting, and thinking is open-ended, hence individual decisions are not determined, because of being rational. A mysterious element of spontaneity is present regarding which components of a situation we attend to, or fail to consider, and how we perceive each one; this goes with our being embedded in a biological, social, historical

${ }^{105} 1 \mathrm{a} 2 \mathrm{ae} 110,2$; 2a2ae 23, 2. 
and geographical context, within which virtuous people take control of their wants and behaviour and, though good citizens, become in some ways less predictable than the majority. Most people settle for moral mediocrity, and fail fully to integrate their emotions, which leaves them susceptible to a wide range of interior and exterior influences, most of which make their behaviour predictable in a dull way (a) as rational enough, and (b) as influenced by factors not personally chosen, nor adequately recognised, evaluated or corrected for:

- "personal chemistry" due to inheritance and upbringing;

- environmental factors;

- law and custom;

- persuasion (now including psychologically astute advertising).

Individual variations in personal chemistry may translate up into statistical regularities.

However, our susceptibility to external influences leaves us vulnerable to factors that are to some extent unpredictable such as mass-movements, whether these are due to psycho-social patterns and forces, or to demons, or to the latter working with the former. Under God's providence, we can also be swayed by forces for the good, whether these are due to charismatic leaders, or to angels, or to the latter working with the former.

In short:

- Human behaviour is, ideally, rationally explicable within a personal variety that conduces to the common good;

- In the majority of cases it is rational enough, so that well-made law and public policy are fairly successful;

- The majority of people will behave in statistically predictable ways owing to their limited success in taking free, personal, rational control of the many less personal factors to which we are susceptible;

- And people at large are liable to be swayed by unpredictable mass-movements for good or ill.

Open Access This chapter is licensed under the terms of the Creative Commons Attribution 4.0 International License (http://creativecommons.org/licenses/by/4.0/), which permits use, sharing, adaptation, distribution and reproduction in any medium or format, as long as you give appropriate credit to the original author(s) and the source, provide a link to the Creative Commons licence and indicate if changes were made.

The images or other third party material in this chapter are included in the chapter's Creative Commons licence, unless indicated otherwise in a credit line to the material. If material is not included in the chapter's Creative Commons licence and your intended use is not permitted by statutory regulation or exceeds the permitted use, you will need to obtain permission directly from the copyright holder.

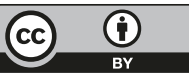

